\title{
KECEMASAN ORANG TUA PADA ANAK DENGAN THALASEMIA DI POLI ANAK RUMAH SAKIT UMUM DAERAH H. ABDUL MANAP KOTA JAMBI TAHUN 2015
}

\author{
Reta Renylda ${ }^{1}$
}

\begin{abstract}
Children with thalassemia must undergo blood transfusions to sustain life and routinely done in periods of continuous lama.Pengobatan will have an impact on psychosocial problems in the family, especially in the elderly. Parents will face a backlash in any care and treatment such as guilt, anxiety, fear, sadness, economic problems and worry about not getting the proper care and treatment.This research is a quantitative descriptive research that aims to describe the level of anxiety of parents of children with thalassemia in Poly Children's Hospital. H. Abdul Manap Jambi City in 2015. The population in this study were all parents whose children suffer from thalassemia as many as 56 people with a total sample of 33 people. This research was conducted on the 26th of June to July 26, 2015 with interview techniques and questionnaires. Results showed that of the 33 respondents, it is as much as 26 respondents (78.8\%) had moderate anxiety level, as many as six respondents (18.2\%) had mild anxiety level and 1 respondent (3\%) had severe anxiety level. It is expected that nurses need to pay attention to and involve parents in performing nursing care in children with thalassemia, and improve the provision of information about the treatment of children to parents, so as to reduce anxiety.
\end{abstract}

\section{Keywords: Anxiety, Parents, Thalassemia}

\section{PENDAHULUAN}

Penyakit kronis merupakan suatu kondisi yang mempengaruhi fungsi harian selama tiga bulan atau lebih dan terjadi dalam satu tahun. Penyakit kronik juga dapat menyerang pada anak, dimana menyebabkan anak harus menjalani hospitalisasi minimal satu bulan dalam satu tahun. Anak yang mengalami penyakit kronis umumnya mendapatkan pengobatan rutin dalam jangka waktu yang lama, hal ini akan mempengaruhi kondisi fisik, psikologis dan kognitif anak sehingga menyebabkan keterbatasan dalam melakukan aktivitas sehari-hari (Hockenberry \& Wilson, 2009).

Salah satu penyakit kronis yang terjadi pada anak adalah penyakit thalasemia, dimana penyakit ini merupakan penyakit kelainan darah yang disebabkan oleh gangguan

\footnotetext{
${ }^{1}$ Akademi Keperawatan Jambi
}

produksi hemoglobin, sehingga jumlah hemoglobin berkurang (Rund \& Rachmilewitz, 2005).

Thalasemia merupakan penyakit PTM yaitu sindrom kelainan yang diwariskan (keturunan) dan masuk ke dalam kelompok hemoglobinopati, merupakan kelainan yang disebabkan oleh gangguan sintesis hemoglobin akibat mutasi di dalam atau dekat gen (Nurarif dkk, 2013).Tanda dan gejala pada anak dengan thalasemia diantaranya perkembangan fisik tidak sesuai dengan umur, lemah, anemia, berat badan berkurang, tidak bisa hidup tanpa tranfusi darah, perubahan bentuk wajah, pembesaran limpa, serta dapat terjadi facecoley, dan hepatomegali (Nurarif dkk, 2013).

Kasus thalasemia dapat terjadi pada laki-laki atau perempuan dan terjadi sebanyak 4.4 dari 10.000 kelahiran hidup. Penderita thalasemia pada tahun 2008 sebanyak 1500 orang 
dan diprediksikan akan meningkat drastis menjadi 22.500 orang pada tahun 2020 (Wibowo, 2010).

Menurut WHO, sekitar $5 \%$ dari seluruh populasi di Dunia adalah carrier thalasemia, dan sekitar 370. 000 bayi lahir dengan kelainan setiap tahunnya. Menurut UNICEF memperkirakan sekitar 29,7 juta pembawa thalasemia beta berada di India dan sekitar 10.000 bayi lahir dengan thalasemia mayor. Menurut Kemenkes RI (2012), prevalensi carrier thalasemia di Indonesia sekitar 3-8 \%. Jika di asumsikan terdapat $5 \%$ carrier dan angka kelahiran 23 per mil dari total populasi di Indonesia 240 juta jiwa. Maka diperkirakan terdapat 3000 bayi penderita thalasemia setiap tahunnya.

Penelitian di Thailand (2007), menyatakan prevalensi thalasemia tinggi di Asia sehingga menyebabkan masalah kesehatan masyarakat dan sosioekonomi (Zaki, 2011). Berdasarkan data yang didapat di Poli Anak RSUD H. Abdul Manap Kota Jambi diperoleh jumlah penderita thalasemia dari tahun 2011 sebanyak 16 orang, tahun 2012 sebanyak 16 orang, dan tahun 2013 mengalami peningkatan yang signifikan yaitu sebanyak 252 orang. Peningkatan ini terjadi dikarenakan pada tahun 2013 RSUD. H. Abdul Manap menjadi pusat pengobatan thalasemia (Rekam Medik, RSU. H. Abdul Manap).

Hockenberry \& Wilson (2009), bahwa anak dengan thalasemia akan membutuhkan dan harus menjalani tranfusi darah yang teratur untuk mempertahankan kehidupannya, selain itu anak juga harus mengkonsumsi obat kelasi besi yang bertujuan untuk mengurangi kelebihan zat besi akibat transfusi darah yang dilakukan secara rutin dan dalam jangka waktu lama.

Transfusi darah dapat memberikan efek samping, dimana kelebihan zat besi akibat transfusi darah dapat menyebabkan pembengkakan limpa dan menyebabkan komplikasi pada hati, ginjal dan jantung (Potts, 2007).

Proses pengobatan thalasemia membutuhkan waktu yang lama dan teratur, oleh karena itu anak yang menderita thalasemia harus terus menjalani pengobatan secara rutin selama berbulan-bulan serta harus mendapatkan dukungan dari orang tua (Klassen, 2011).

Meningkatnya beban psikologis keluarga akibat pengobatan yang berlangsung secara terus-menerus dalam merawat anak dengan thalasemia akan berdampak pada masalah psikososial pada keluarga, salah satu masalah psikososial yang terjadi adalah kecemasan (ansietas).

Kecemasan merupakan gangguan alam perasaan (afektif) yang ditandai dengan perasaan ketakutan atau kekhawatiran yang mendalam, tidak mengalami gangguan dalam menilai realitas, perilaku dapat terganggu tetapi masih dalam batas normal (Hawari, 2013).

Menurut Stuart (2013), tingkatan kecemasan terdiri dari kecemasan ringan, kecemasan sedang, kecemasan berat dan panik. Tanda dan gejala kecemasan menurut Hawari (2013),yaitu khawatir, berdebar-debar, firasat buruk, gelisah, merasa tegang, mudah tersinggung, takut akan pikiran sendiri, gangguan pola tidur serta gangguan konsentrasi dan daya ingat.

Orang tua yang mengalami cemas dikarenakan anaknya menderita thalaemia akan melakukan tindakan overprotektif, perasaan tanggung jawab dan rasa bersalah pada anaknya, mengalami gangguan tidur serta merasa tidak berharga dalam menghadapi masalah (Jenerette \& Valrie, 2010).

Penelitian Yumazaki (2006) pada orang tua dengan anak thalasemia kecenderungan mengalami gangguan 
pada mental dan fungsi sosial. Gangguan psikologis yang ditemukan seperti perasaan bersalah, marah, sedih, dan tidak percaya, takut tertekan dan cemas dapat dirasakan menetap sampai 5 tahun dan dapat kembali normal setelah beberapa tahun (Norberg \& Boman, 2008).

Studi pendahuluan yang dilakukan oleh peneliti pada tanggal 22 Maret 2015, berdasarkan hasil wawancara terhadap 10 orang ibu yang memiliki anak penderita thalasemia bahwa 9 dari 10 orang ibu mengatakan cemas dan takut saat mengetahui anaknya menderita penyakit thalasemia.

Berdasarkan fenomena yang telah diuraikan diatas, diketahui bahwa orangtua yang menghadapi perawatan dan pengobatan pada anak dengan thalasemia dapat mempengaruhi psikososial orang tua, salah satunya adalah kecemasan. Dengan demikian peneliti tertarik untuk melakukan penelitian tentang kecemasan orang tua pada anak dengan thalasemia.

\section{METODE PENELITIAN}

Penelitian ini merupakan penelitian Deskriptif Kuantitatif yang bertujuan untuk mengetahui kecemasan orang tua pada anak dengan thalasemia di Poli Anak RSUD. H. Abdul Manap Kota Jambi. Populasi dalam penelitian ini adalah orang tua yang memiliki anak dengan thalasemia sebanyak 56 orang dengan jumlah sampel sebanyak 33 orang. Penelitian ini dilakukan pada tanggal 26 Juni sampai 26 Juli 2015.

\section{HASIL DAN PEMBAHASAN}

Hasil penelitian yang dipaparkan meliputi karakteristik responden, kecemasan orang tua pada anak dengan thalasemia di Ruang poli Anak RSUD. H. Abdul Manap Kota Jambi.

\section{Karakteristik Responden}

Distribusi kecemasan orang tua dengan anak thalasemia berdasarkan usia, pendidikan, penghasilan dan pengetahuan dapat dilihat pada tabel 1 .

Tabel 1: Distribusi Frekuensi

Karakteristik Responden

\begin{tabular}{clcc}
\hline No & $\begin{array}{c}\text { Karakteristik } \\
\text { Responden }\end{array}$ & N & $\%$ \\
\hline 1 & Usia & & \\
& $24-30$ & 3 & 9,10 \\
& $31-40$ & 16 & 48,2 \\
& $>40$ & 14 & 42,2
\end{tabular}

2 Pendidikan

$\begin{array}{lcc}\text { SD } & 6 & 18,2 \\ \text { SMP } & 7 & 21,2 \\ \text { SMA } & 13 & 39,4 \\ \text { PT } & 7 & 21,2\end{array}$

3 Jenis kelamin

$\begin{array}{lcc}\text { Laki-laki } & 7 & 21,2 \\ \text { Perempuan } & 26 & 78,8\end{array}$

4 Pekerjaan

\begin{tabular}{lcc} 
Swasta & 5 & 15,2 \\
PNS & 7 & 21,2 \\
Wiraswasta & 10 & 30,3 \\
IRT & 11 & 33,3 \\
\hline
\end{tabular}

Hasil penelitian menunjukkan orang tua pada anak dengan thalasemia mayoritas usia orang tua anak thalasemia yaitu usia dewasa 31-40 tahun (48,2 \%), Pendidikan SMA $(39,4 \%)$, Jenis kelamin perempuan $(78,8 \%)$, dan Pekerjaan sebagian besar IRT $(33,3 \%)$.

Tabel 2 : Distribusi Frekuensi Kecemasan Orang Tua Pada Anak dengan Thalasemia

\begin{tabular}{clcc}
\hline No & Kecemasan & n & \% \\
\hline 1 & Ringan & 6 & 18,2 \\
2 & Sedang & 26 & 78,8 \\
3 & Berat & 1 & 3 \\
\hline
\end{tabular}

Hasil penelitian menunjukkan kecemasan orang tua dengan anak thalasemia yaitu kecemasan sedang 26 $(78,8 \%)$. 


\section{Data Demografi}

Hasil penelitian menunjukkan orang tua pada anak dengan thalasemia mayoritas usia orang tua anak thalasemia yaitu usia dewasa 31-40 tahun $(48,2 \%)$. Menurut Kaplan \& Saddock (2010) dalam Dini (2012), bahwa semakin bertambah usia seseorang, maka semakin baik tingkat kematangan emosi seseorang serta kemampuan dalam menghadapi berbagai permasalahan.

Hasil penelitian mendapatkan sebagian besar tingkat pendidikan orangtua yaitu Sekolah Menengah Atas (SMA) sebanyak 13 responden $(39,4 \%)$.Pendidikan merupakan proses dari hasil belajar pada suatu lembagapendidikan dengan berbagai jenjang pendidikan. Seseorang yang mempunyai pendidikan yang tinggi akan memiliki perkembangan kognitif yang tinggi juga, sehingga diharapkan seseorang dapat menerima informasi dengan baik. Pendidikan orang tua yang rendah dapat berdistribusi terhadap rendahnya pengetahuan tentang perjalanan penyakit yang diderita oleh anaknya (Dini, 2012).

\section{Kecemasan Orang Tua Pada Anak Dengan Thalasemia}

Berdasarkan hasil penelitian didapatkan dari 33 responden mayoritas orang tua mengalami kecemasan sedang 26 responden $(78,8 \%)$, kecemasan ringan sebanyak 6 responden $(18,2 \%)$ dan kecemasan berat sebanyak 1 responden (3\%). Penelitian ini sejalan dengan penelitian Rachmania (2012) tentang gambaran tingkat kecemasan dan koping orang tua dalam merawat anak dengan thalasemia mayor, didapatkan sebanyak 47 orang tua $(55 \%)$ mengalami kecemasan sedang dalam merawat anak dengan thalasemia.

Menurut Stuart (2013), kecemasan merupakan timbulnya rasa takut yang tidak jelas dan disertai dengan perasaan ketidakpastian, ketidakberdayaan, isolasi dan ketidakamanan.

Menurut Dalami (2009), kecemasan merupakan respon emosional terhadap penilaian individu yang subjektif, yang dipengaruhi oleh alam bawah sadar dan tidak diketahui secara pasti penyebabnya.

Faktor kecemasan sendiri dipengaruhi oleh beberapa faktor, seperti usia, jeniskelamin, pengalaman sebelumnya, kondisi medis (diagnosis penyakit), tingkat pendidikan dan sosial ekonomi.Usia merupakan salah satu faktor yang berkontribusiterhadap timbulnya kecemasan, dimana usiamuda lebih mudah mengalami kecemasandibanding yang tua, namun dapat pulasebaliknya. Pada dewasa lanjut, kecemasankarena faktor usia dapat muncul karena usiasedikit banyaknya berkaitan denganpengalaman masa lalu terhadap hal yang sama (Kaplan \& Saddock, 2010).

Selain usia dan tingkat pendidikan, kecemasan juga dapat dipengaruhi oleh tingkat pendidikan dan jenis kelamin. Wanita lebih sering mengalami kecemasan dari pada pria. Wanita mempunyai tingkat kecemasan lebih tinggi dari pria, dikarenakan bahwa wanita lebih peka terhadap emosinya yang diakhirnya mempengaruhi perasaan cemas (Kaplan \& Saddock, 2010) Pada penelitian ini mayoritas responden adalah perempuan sebanyak 26 responden $(78,8 \%)$.

Menurut asumsi peneliti,
kecemasan merupakan respon emosional orang tua yang sering dialami oleh orang tua ketika ada masalah kesehatan yang terjadi pada anaknya. Adanya dukungan dan informasi kesehatan yang adekuat tentang penyakit yang diderita anaknya 
akan dapat membantu mengurangi kecemasan.

\section{SIMPULAN}

Berdasarkan hasil penelitian dan uraian pembahasan dapat disimpulkan tentang kecemasan orang tua pada anak dengan thalasemia.

1. Karakteristik responden

a. Berdasarkan usia, sebagian besar berusia 31-40 tahun sebanyak 16 responden $(48,5 \%)$

b. Berdasarkan tingkat pendidikan, sebagian besar tingkat pendidikan responden adalah SMA sebanyak 13 responden $(39,4 \%)$.

c. Berdasarkan jenis kelamin, sebagian besar jenis kelamin responden adalah perempuan sebanyak 26 responden $(78,9 \%)$.

d. Berdasarkan pekerjaan, sebagian besar responden adalah IRT sebanyak 11 responden $(33,3 \%)$.

2. Kecemasan orang tua pada anak dengan thalasemia, diketahui mayoritas mengalami kecemasan sedang yaitu sebanyak 26 responden $(78,8 \%)$.

\section{Saran}

a. Bagi Pelayanan Keperawatan

Diharapkan agar dapat lebih meningkatkan pelayanan, terutama dalam pemberian informasi tentang pengobatan anak dengan thalasemia sehingga dapat mengurangi kecemasan pada orang tua.

b. Bagi Institusi Pendidikan

Meningkatkan pemahaman pada peserta didik, bahwa masalah psikososial merupakan salah satu kebutuhan dasar manusia dan harus sehingga lebih dioptimalkan dalam melakukan asuhan keperawatan dan memberikan edukasi pada pasien dengan masalah psikososial.

c. Bagi Penelitian selanjutnya

Disarankan untuk peneliti selanjutnya dapat melakukan penelitian lanjutan tentang penanganan kecemasan orang tua dalam menghadapi anak dengan thalasemia.

\section{DAFTAR PUSTAKA}

Dalami, E, dkk. (2009). Asuhan Keperawatan dengan Masalah Psikososial. Jakarta : EGC

Dini, (2012). Faktor-Faktor Penyebab Thalasemia. Skripsi UI.Tidak diPublikasikan

Friedman, M. (2010).Buku Ajar Keperawatan Keluarga. Riset, Teori \& Praktik. Edisi 5. Jakarta :EGC

Hawari. (2009). Hubungan Tingkat Kecemasan Orang Tua Dalam Pengobatan Anak Dengan Thalasemia. Skripsi USU.Tidak diPublikasikan

Hawari. (2013). Manajemen Stres, Cemas, dan Depresi. Jakarta : Fakultas Kedokteran UI

Hokenberry \& Wilson (2009).Wong's Nursing Care Of Infants And Children.Ed.8. St. Louis : Mosby Jenerette, C.M. \&Valrie, C.R. (2010).The Influence of Maternal Behaviors During Childhood on Self Efficacy in Individuals with Sickle Cell Disease. Journal of Family Nursing.16.422-434.

Kaplan, I. H., Sadock, B. J., Grebb, J. A. (2010). SinopsisPsikiatrillmuPengetahua nPerilaku PsikiatriKlinis. Tangerang: BinarupaAksara

Kemenkes RI. (2012). Thalasaemia Bukan penyakit Menular. Jakarta : Pusat KomunikasiPublik Sekjen Kemenkes RI

Klassen, F. A., Gulati, S., Granek, L., Rosenberg-Yunger, R. S. Z., Watt, L., Sung, L., Klaassen, R., Dix, D., \& Shaw, T. N. (2011). Understanding the health impact of caregiving: a qualitative study of immigrant parents and single parents of children with 
cancer.Qual Life Res, 21, 15951605

Nathan\&Oskis's (2009).Leterature Notes Pediatric. Edisi 7. Jakarta. Erlangga.

Nurarif, A. H \& Kusuma, H. (2013). Aplikasi Asuhan Keperawatan Berdasarkan Diagnosa Medis \& NANDA NIC NOC. Jilid 2. Jakarta: EGC

Pots, N.L. \& Mondleco, B.L. (2007). Pediatric Nursing; Caring for children and their families (2nd ed). New York:Thomson Corporation

Rachmaniah, D. (2012). Pengaruh Psikoedikasi Terhadap Kecemasan dan Koping Orang Tua Dalam Merawat Anak Dengan Thalasemia Mayor di RSU Kabupaten Tangerang Banten. Jakarta: Fakultas Ilmu Keperawatan UI : Tidak dipublikasikan

RekamMedis RSUD. Data Penderita Thalasemia di RSUD H. Abdul Manap Jambi

Stuart, W. (2013). Prinsip dan Praktik Keperawatan Kesehatan Jiwa. Edisi Indonesia. Jakarta : Fakultas Keperawatan Indonesia

Wong, D.L., Hockenberry, M., Wilson, D.Winkelstein, M.L., \& Schwartz, P.(2009). BukuAjar Keperawatan Pediatrik, Edisi 6. Jakarta:EGC 